\title{
Students' perceptions of the infopreneurship education in the Department of Records and Archives Management at the National University of Science and Technology
}

\begin{tabular}{|c|c|}
\hline \multicolumn{2}{|c|}{$\begin{array}{l}\text { Authors: } \\
\text { Peterson Dewah }{ }^{1} \\
\text { Stephen Mutula }{ }^{1}\end{array}$} \\
\hline \multicolumn{2}{|c|}{$\begin{array}{l}\text { Affiliations: } \\
{ }^{1} \text { School of Social Sciences, } \\
\text { Information Studies } \\
\text { Programme, University of } \\
\text { KwaZulu-Natal, South Africa }\end{array}$} \\
\hline \multicolumn{2}{|c|}{$\begin{array}{l}\text { Corresponding author: } \\
\text { Peterson Dewah, } \\
\text { dewah@ukzn.ac.za }\end{array}$} \\
\hline \multicolumn{2}{|c|}{$\begin{array}{l}\text { Dates: } \\
\text { Received: } 22 \text { Oct. } 2015 \\
\text { Accepted: } 17 \text { Mar. } 2016 \\
\text { Published: } 12 \text { Oct. } 2016\end{array}$} \\
\hline \multicolumn{2}{|c|}{$\begin{array}{l}\text { How to cite this article: } \\
\text { Dewah, P. \& Mutula, S., 2016, } \\
\text { 'Students' perceptions of the } \\
\text { infopreneurship education in } \\
\text { the Department of Records } \\
\text { and Archives Management at } \\
\text { the National University of } \\
\text { Science and Technology', } \\
\text { South African Journal of } \\
\text { Information Management } \\
\text { 18(1), a717. http://dx.doi. } \\
\text { org/10.4102/sajim.v18i1.717 }\end{array}$} \\
\hline \multicolumn{2}{|c|}{$\begin{array}{l}\text { Copyright: } \\
\text { (C) 2016. The Authors. } \\
\text { Licensee: AOSIS. This } \\
\text { is licensed under the } \\
\text { Creative Commons } \\
\text { Attribution License. }\end{array}$} \\
\hline \multicolumn{2}{|l|}{ Read online: } \\
\hline apidn & $\begin{array}{l}\text { Scan this QR } \\
\text { code with your } \\
\text { smart phone or } \\
\text { mobile device } \\
\text { to read online. }\end{array}$ \\
\hline
\end{tabular}

Background: The infopreneurship education course forms part of the final year Bachelor of Science Honours Degree in Records and Archives Management (BScRAM) at the National University of Science (NUST). The course looks unique and out of place in relation to other records and archives courses which specifically focus on the management of records and archives.

Objectives: The study examined the students' perceptions regarding the relevance of the infopreneurship course in the BSCRAM that is offered in the Department of Records and Archives Management at NUST, Zimbabwe. The aim of the study was to determine student evaluation of relevance of the course to the BScRAM.

Method: Both quantitative and qualitative methods of collecting data were used. Using a census method, data was collected through a focus group interview and a self-administered questionnaire from a study population that comprised 17 students who were in their final year of the BScRAM at NUST.

Results: The results revealed students found the infopreneurial education module quite relevant to their degree. Although the lecturer was helpful in providing resources, students felt that they needed to visit some infopreneurial businesses for familiarisation and looked forward to having guest lecturers from the infopreneurial world.

Conclusion: Although the BScRAM was not well known at high school level, students found the infopreneurial education in this degree quite stimulating. Having gone through an infopreneurship course, students were prepared to undertake infopreneurial businesses after graduating from the university.

\section{Introduction}

The term infopreneur is derived from information and entrepreneur. Entrepreneurship is the process of starting a business, based around an innovative product, process, or service. Weber (2012) defines entrepreneurship as the discovery, evaluation, and exploitation of opportunities to create future goods and services by a natural individual through the creation of a new organisation. Infopreneur refers to an entrepreneur who makes a living by producing, collecting, gathering, repacking, disseminating, developing, and selling information and information products and services for a profit, in most cases via the internet (Du Toit 2000; Chandler 2007; Lahm \& Stowe 2011). Infopreneurship is part of what Ocholla (1999) described as information consultancy and brokerage. An entrepreneurial personality identifies with a set of traits such as need for achievement, locus of control, risk-taking propensity, desire for autonomy, overoptimistic about chances of being successful, and tolerance for ambiguity (Storey \& Greene 2010) among other useful traits that make an individual a successful entrepreneur in information.

Universities worldwide use various methods to teach entrepreneurship. Many scholars and educators agree that entrepreneurship education is intended to encourage and stimulate the creation of new ventures through increasing students' awareness of entrepreneurship as a process and a distinct career possibility (Kassean et al. 2015; Blenker et al. 2006). Entrepreneurship education culminates in establishment of business for the purposes of profit making and growth, and self-employment in contrast to organisational employment. In Weber's (2012) view entrepreneurship education has two purposes: (1) to increase students' entrepreneurial skills and (2) to provide impetus to those who are suited to entrepreneurship while discouraging those who 
are not. Individuals engage in infopreneurship for various reasons, chief among them being unemployment and the desire to be self-employed.

A study conducted in Botswana, Ocholla (1999; 1998) identified a host of some reasons for engaging in infopreneurship including the following:

- decline of resources to sustain wage employment in the public and private sector

- increase in unemployment calling for self-employment

- dead end jobs retarding professional and career growth

- the inability of existing information provision centres to provide information services needed, and increased demand for specialised information services

- the willingness of information consumers to pay for consultancy services and recognition that information is a commodity that can create wealth

- acceptance that information is power necessary for individuals and firms to stay in the market and to keep the competition off-balance

- interest in self-employment; inadequate incomes force income earners to sell skills and knowledge for additional earnings

- social change witnessed in the creation of small businesses

- encouragement by entrepreneurs who buy expertise, hire consultants, and avoid obligations for hiring staff on a long-term basis

- increased need for proper information management

- size and complexity of the information industry (Ocholla 1999; 1998).

Other areas of infopreneurship could include internet providers; e-services and m-services; computer troubleshooting services; helping junior students write research proposals, essays, and reports; proofreading; editing (Ramugondo 2010); and such areas as e-books and e-publishing; business analyst consultancy; web newsletters, access achieved through subscription; and online solutions through recorded videos, for example on how to reference, how to publish online, and how to write a winning research proposal (Chandler 2007).

In a Botswana study Ocholla $(1999 ; 1998)$ identified research in information related fields such as:

- user studies and market analysis

- compilation of bibliographic lists

- provision of current business information

- compilation of directories

- publishing, for instance desktop publishing

- translation services; information repackaging

- writing, editing, proofreading; collection management

- records management; management of service established through consultancy services

- cataloguing

- document delivery services

- development of specialised libraries from scratch

- software creation and development; development vocabularies
- search and retrieval of information

- conduct staff training

- newspaper clipping services

- online searching; organisation of files and planning of paper flow

- organisation of seminars, workshops and conferences and preparation of proceedings, provision of current awareness and alerting information services among others.

Information consultancy can provide a wide range of services in Records and Archives Management (RAM), for instance filing, reorganising the registry, automating records offices, digitisation projects of records or archives, and training services, among others.

\section{Contextual setting: Teaching infopreneurship in the Records and Archives Management Department at the National University of Science and Technology}

The National University of Science and Technology (NUST) was founded in 1988. Its vision is 'to be a world-class centre of excellence in teaching, research, innovation and entrepreneurship for sustainable development' (NUST 2015) and its mission statement is to 'contribute positively towards the advancement of humanity through the provision of knowledge based solutions to scientific, technological, economic and social challenges'. NUST hopes to achieve its mission and goals through a coterie of core values, namely honesty and integrity, innovativeness, excellence and diligence, intellectual freedom, equity, and social, and environmental responsibility.

The NUST is comprised of seven faculties (Applied Sciences, Commerce, Communication \& Information Science, Built Environment, Medicine, Industrial Technology, and Faculty of Technical Teacher Education) consisting of 32 different departments. A run through the university's yearbook reveals that the majority of the departments teach entrepreneurial courses to either undergraduates or postgraduate students. Cited in Keat, Selvarajah and Meyer (2011), observes that courses in entrepreneurship are also becoming popular at college and university levels. Regarding entrepreneurship education Blenker's et al. (2006) assume that entrepreneurship or enterprising behaviour characteristics, competencies, and skills can be learned and taught. Kirby (2007) argues that in this era of rapid change universities should develop in students the abilities to see opportunities, cope with uncertainty, and bring about change through innovation.

The department of Records and Archives Management (RAM) is housed under the Faculty of Communication and Information Science together with the departments of Library and Information Science, Journalism and Media Studies, 
and Publishing. In the first semester of their final year RAM students cover Management of Records Centres, Information Economics, Marketing of Information Products and Services, Management of Health Information, and infopreneurship courses. At the time of the study the department had seven lecturers, two staff development fellows, three teaching assistants, and one research fellow (NUST 2015). Johannisson (1991) and as cited in Fayolle, Gailly and Lassas-Clerc (2007) are of the opinion that the impact of students' perceptions of entrepreneurship, along with resources and other support mechanisms available in the university environment, can positively influence student attitudes towards entrepreneurial careers. Fayolle et al. (2007) opine that the significant differences between students who have taken entrepreneurship courses and those who have not can be explained by the educational variables (course content, teaching methods, teacher profile, resources, and support) and the direct intentional and behavioural antecedents (attitudes, values, knowledge, and so on).

Weber (2012) has observed that although students express interest about entrepreneurship, they lack information and as such entrepreneurship courses may provide a welcome source of information and skills. An infopreneurship course was introduced to the RAM Department in 2011 and to date it has had four cohorts of graduates. This was in line with the vision, mission, and core values of NUST which entail equipping NUST graduates with entrepreneurial skills in order to start their own businesses and fend for themselves rather than seek to be employed by others. Keat et al. (2011) are of the view that many universities and colleges around the world have introduced entrepreneurial courses to students in an effort to promote entrepreneurship as well as a professional entrepreneurship career. Blenker et al. (2006) reveal that traditionally universities have focused on teaching students what the university finds necessary.

Weber (2012) identified six elements of entrepreneurship education:

- objectives that are pursued

- faculty or teaching team who will be imparting it

- participant students

- content of the course

- teaching methods

- specific support activities for the participants to start their ventures.

The course description clearly outlines that after studying this course, among other outcomes and expectations, students should be able to conceptualise the current world in which people work with information as a living function; discuss the characteristics of an information society and give reasoned views of whether Zimbabwe or part of the country, measures up to these characteristics; set up an information business; and develop a business plan. Various methods are designed to assist students learn entrepreneurial skills. Kassean et al. (2015) suggest that many entrepreneurship programs aim to expose students to role models in the form of guest speakers, consulting projects, and mentoring programs. Education, training, and mentoring for aspiring and established entrepreneurs are intended to develop entrepreneurs (Henry \& Letch 2007).

The 2014 course outline had six units:

- the information world

- business of information

- entrepreneurship and information

- starting and managing a new business

- business ethics

- developing a business plan.

Chandler and Jansen (1992) cited in Carrier (2007) are of the view that entrepreneurs must acquire three types of competencies, namely entrepreneurial, managerial, and technical competencies.

It was noticeable that topics such as risk taking and market research were absent from the course outline. Kyro and Tapani (2007) observe that risk-taking from learning and teaching perspectives has been a neglected area in entrepreneurship education research such that they believe risk-taking is a competence that can be both taught and learned. With regards to marketing, Hills, Hultman and Miles (2007) have noted that marketing educators, using traditional marketing principles, typically encourage students to develop a marketing plan. An important part of marketing education focuses on how companies obtain information about the environment (Hills et al. 2007). The course outline gives some activities and cases as a way to enhance learning. Assignment topics are listed so that students choose and answer them as part of their coursework. Assessment of the course is well explained in the course outline. A reference list is appended to assist students in their further research. The infopreneurship course is offered in the first semester of the fourth/final year and to date the RAM department has graduated four streams in this course. It remains to be seen how many graduates have started their businesses. Maybe this deserves a follow-up study by another researcher. Kirby (2007) suggests that to develop an individual who can identify opportunities requires a change in the courses, the process of learning, and in some cases the place where learning takes place.

\section{Statement of the problem}

The infopreneurship course forms part of the final year Bachelor of Science Honours Degree in Records and Archives Management (BScRAM). The course looks unique and out of place in relation to other courses which specifically focus on the management of records and archives. Because of substantial changes, transformations, and demands on an entrepreneur's skills and abilities, entrepreneurship educators need to formulate flexible strategies to allow for continual redesign of organisations, and find alternative and non-traditional methods of teaching entrepreneurship. Absence of some key topics such as risk and market research requires an inquiry on students' perceptions on the 
infopreneurship course. As such the study aimed at assessing the RAM students' perceptions on the infopreneurship course that forms part of their courses in the final year of BScRAM.

\section{Research questions}

The main research question this paper sought to address was: what are the RAM students' perceptions on the infopreneurship education course offered in the study of records and archives management degree? The following specific research questions are addressed.

- What motivated students to enrol for the BSc degree in Records and Archives Management at NUST?

- How relevant is the infopreneurship course in the study of Records and Archives Management?

- Do resources suffice to assist students undertaking the course?

- What challenges do final/fourth year students face in undertaking this course?

- Would the students want to become infopreneurs after graduation?

- What recommendations can be made to the RAM department to facilitate smooth running of the course?

In spite of the fact that entrepreneurship is offered to students across the university faculties, this study was delimited to the Faculty of Communication and Information Science's Records and Archives Management Department. Anecdotal evidence by one of the researchers who is a member of staff in that faculty pointed to the fact that the RAM department was the only department that offered an infopreneurship module in that faculty at the time of the study and only at fourth/final year level. The other departments (Library and Information Science, Publishing Studies, and Media and Journalism) shop for the entrepreneurship course from the Faculty of Commerce.

\section{Methodology}

The study used both quantitative and qualitative methods of collecting data. A self-administered questionnaire was distributed to all the 17 fourth/final year students who were taking the infopreneurship module during the final year of their degree. The study used the census method. The census was appropriate to this small and heterogeneous group of 17 students. The students completed and returned the questionnaires through their class representative. Sixteen completed questionnaire copies were returned and one student did not return the questionnaire. This gave a response rate of 94\%. Quantitative data was analysed statistically using SPSS version 18 , whereas qualitative data was analysed thematically. The researcher conducted a focus group interview with six students (two males and four females) to seek clarifications on certain questions. The interview lasted for $90 \mathrm{~min}$.

Data gathered revealed that all students were Zimbabweans and enrolled for the BSc Honours degree in Records and Archives Management at this university in 2011. Eleven female and 5 male fourth and/or final year students took part in the study. Fourteen $(87.5 \%)$ respondents were between the ages of $22-24$ years, $1(6.2 \%)$, was in the $19-21$ year age group, and 1 (6.2\%), was above 25 years of age.

\section{Data presentation and analysis Students' motivation for enrolling for the Bachelor of Science Honours Degree in Records and Archives Management}

Students were asked to give their reasons for choosing and enrolling for the BScRAM at NUST. This was a qualitative question. Student responses were put under themes and the following are responses from the questionnaire and focus group interview: 'it is an emerging professional discipline in Zimbabwe'; 'the university chose the programme for me'; 'the management of records is applicable to many organisations'; 'I was fascinated about the programme'; 'the programme is not yet flooded on the market'; 'I saw the newspaper advert'; 'somebody encouraged me'; 'mentor advised me to take the degree programme'. It also emerged that the majority of the students who took part in the focus group interview wanted degree programmes that are offered in the Faculty of Commerce at the same university. The degrees they mentioned included, BSc Honours Marketing, BSc Honours Accounting and BSc Honours Business Management.

\section{Relevancy of the infopreneurship education in records and archives}

Given that it is a course slightly different from other courses that are found in the BScRAM, students were asked if they think it was a relevant course in RAM. The responses from both questionnaire and interviews revealed that students found it very relevant in the degree programme and in preparing them for future life. Their answers were grouped thus 'equips with knowledge in infopreneurial activity'; 'role of information professional is changing with technology' and 'learned creative analytical skills' (Figure 1).

From the interviews students pointed out that the BScRAM provides them with basic foundation knowledge in the management of records. Infopreneurship then gives skills to

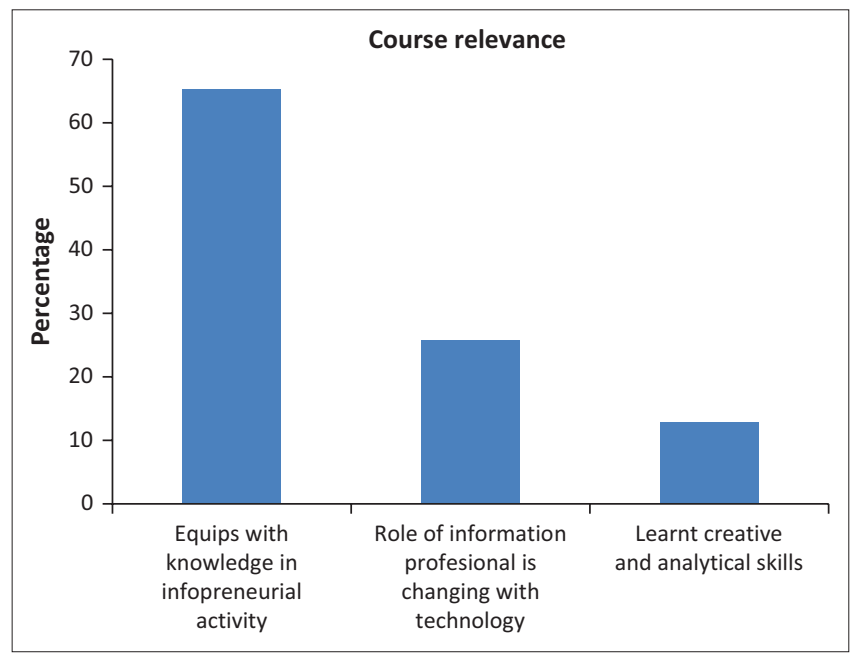

FIGURE 1: Relevancy of the infopreneurship course in records and archives $(N=16)$. 
sell information and skills to start their own businesses through good proposal writing. Students went on to suggest that in a university they may start businesses to proofread research projects. In view of all these they concluded that infopreneurship was a relevant course to them.

The questionnaire provided the students with a list of all the six units that they covered as stated in the course outline. Students were then asked to identify those units which they found relevant and or irrelevant to the BScRAM. Results indicate that students found all the five units (the information world; business of information; entrepreneurship and information; starting and managing a new business; business ethics, and developing a business plan) to be relevant and appropriate to be taught in the course.

\section{Students' evaluation of the infopreneurship course}

The course Infoprenuership (Code IRA 4104) was offered to fourth and/or final year students in the first semester in 2014. Students were then asked for their opinions on how they found this course. The question required them to fill in their opinions in the spaces provided. A qualitative analysis grouped the responses under seven themes and this was presented diagrammatically in Figure 2. Students' views were as follows: 'very interesting course' (9: 56\%); 'promotes innovation' (2: 13\%); 'highlights gaps that can be exploited' (1: 6\%); 'equips with entrepreneurial skills' (1: 6\%); 'easy to understand' (1: 6\%), 'good foundation' (1: 6\%) and 'fair' (1: 6\%). The students' views are presented in Figure 2.

During the focus group interview students made the following additional comments: 'the course was an eye-opener'; 'I was fascinated'; 'I saw other job opportunities to earn money' and 'the course opened avenues for RAM graduates to do something' suggesting that the Theory of Planned Behaviour is appropriate in predicting entrepreneurial activity (Weber 2012) as future behaviour of students.

\section{Infopreneurship course content}

In view of what was covered in their course outline students were asked to tick those topics that they felt needed to be

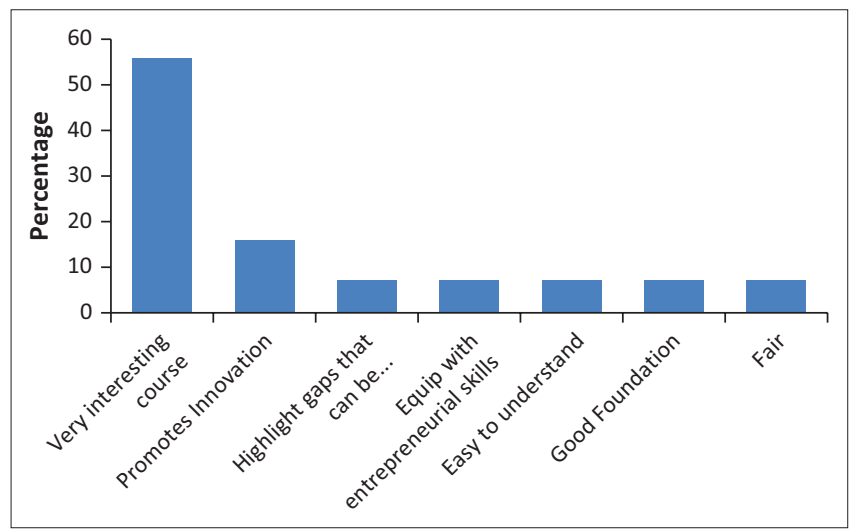

FIGURE 2: Students' evaluation of infopreneurship course $(N=16)$. added to the course content. In the responses 'strongly agree' and 'agree' were treated as 'agree'. Similarly 'disagree' and 'strongly disagree' were treated as 'disagree'. Results indicated that the majority of students agreed that risk and the entrepreneur (15: 93\%), infopreneurship in Zimbabwe (14: $87 \%$ ) were frequently mentioned, followed by market research (13: 81.3\%). The others were entrepreneurship (11: 68\%), marketing management (10: 62.6\%), personnel management (8: 50\%), and financial management (9: 56.3\%). Students were not sure if financial management (6: 37.5\%), personnel management (5: 31.3\%), marketing management (4: 25\%), entrepreneurship (4: 25\%), market research (2: $12.5 \%)$ and infopreneurship in Zimbabwe (2: 12.5\%) could be added to the infopreneurship course. Nobody objected/ disagreed to the inclusion of financial management, risk and the entrepreneur, and infopreneurship in Zimbabwe. Three $(18.8 \%)$ students disagreed that personnel management could be added. There were single objections to the inclusion of market research (1: 6.3\%), marketing management (1: $6.3 \%)$, and entrepreneurship (1: $6.3 \%$ ) topics. Teaching these topics to students is consistent with Chandler and Jansen's (1992) view as cited in Carrier (2007) that entrepreneurs must acquire entrepreneurial, managerial, and technical competencies.

The focus group interview revealed that respondents disagreed (3: 18.8\%) that personnel management should be added to course outline because the students cover this title in a shopped module (Principles of Management and Business Ethics) from the faculty of commerce. The five (31.3\%) respondents who remained neutral probably thought there could be something special/unique with personnel management in infopreneurship or that it was not necessary to do personnel management again. During the interview students pointed out that considering the Zimbabwean economic situation, another topic called 'Information in Zimbabwe' needed to be added.

During the focus group interview students revealed that risk and the entrepreneur must be included because 'information has its risks' and therefore needed 'risk takers'. The absence of risk as a topic in the course confirms Kyro and Tapani's (2007) view that students' feelings and perceptions about risk-taking, uncertainty, and insecurity are rarely studied in entrepreneurship research yet they are valid in entrepreneurship education. Respondents also suggested that market research was important because the infopreneur needs to 'know what consumers want' confirming Hills et al. (2007) observation that marketing research is the leading source of information about the environment.

\section{Challenges faced by the fourth or final year students in undertaking this course}

In view of challenges of taking a relatively new course in the university curricula, respondents were asked to rate the lecturer's support in helping the student's education on infopreneurship. Data obtained revealed that the lecturer 
TABLE 1: Courses to be added to the existing course outline $(N=16)$.

\begin{tabular}{|c|c|c|c|c|c|c|c|c|c|c|}
\hline \multirow[t]{2}{*}{ Suggested courses to be added } & \multicolumn{2}{|c|}{ Strongly agree } & \multicolumn{2}{|c|}{ Agree } & \multicolumn{2}{|c|}{ Neutral } & \multicolumn{2}{|c|}{ Disagree } & \multicolumn{2}{|c|}{ Strongly disagree } \\
\hline & $n$ & $\%$ & $n$ & $\%$ & $n$ & $\%$ & $n$ & $\%$ & $n$ & $\%$ \\
\hline Financial Management & 3 & 18.8 & 6 & 37.5 & 6 & 37.5 & - & - & - & - \\
\hline Risk and the entrepreneur & 12 & 75 & 3 & 18.8 & - & & - & - & - & - \\
\hline Infopreneurship in Zimbabwe & 12 & 75 & 2 & 12.5 & 2 & 12.5 & - & - & - & - \\
\hline Market research & 9 & 56.3 & 4 & 25 & 2 & 12.5 & 1 & 6.3 & - & - \\
\hline Marketing Management & 5 & 31.3 & 5 & 31.3 & 4 & 25 & - & - & 1 & 6.3 \\
\hline Personnel Management & 4 & 25 & 4 & 25 & 5 & 31.3 & 2 & 12.5 & 1 & 6.3 \\
\hline Entrepreneurship & 4 & 25 & 7 & 43.8 & 4 & 25 & - & - & 1 & 6.3 \\
\hline
\end{tabular}

TABLE 2: Lecturer's support $(N=16)$.

\begin{tabular}{|c|c|c|c|c|c|c|c|c|c|c|}
\hline \multirow[t]{2}{*}{ Lecturer's activities and initiatives } & \multicolumn{2}{|c|}{ Not helpful at all } & \multicolumn{2}{|c|}{ Not sure } & \multicolumn{2}{|c|}{ Helpful } & \multicolumn{2}{|c|}{ Very helpful } & \multicolumn{2}{|c|}{ Extremely helpfu } \\
\hline & $n$ & $\%$ & $n$ & $\%$ & $n$ & $\%$ & $n$ & $\%$ & $n$ & $\%$ \\
\hline Conducted lectures & - & - & - & - & 2 & 12.5 & 9 & 56.3 & 5 & 31.3 \\
\hline Provided books & - & - & - & - & 6 & 37.5 & 3 & 18.8 & 6 & 37.5 \\
\hline Provided journal articles & - & - & - & - & 4 & 25 & 3 & 18.8 & 9 & 56.3 \\
\hline Provided course outline & - & - & - & - & 3 & 18.8 & 3 & 18.8 & 10 & 62.5 \\
\hline Provided practical speeches by Infopreneurs & 6 & 37.5 & 4 & 25 & 2 & 12.5 & - & - & 2 & 12.5 \\
\hline Group visits to Information businesses & 7 & 43.8 & 3 & 18.8 & 1 & 6.3 & 1 & 6.3 & 2 & 12.5 \\
\hline Lecturer related his own infopreneurship experience & 2 & 12.5 & 3 & 18.8 & 5 & 31.3 & 1 & 6.3 & 3 & 18.8 \\
\hline
\end{tabular}

was helpful by conducting lectures $16(100 \%)$, providing books $16(100 \%)$, providing journal articles $16(100 \%)$, and providing the course outline $(100 \%)$. Dilts and Fowler (1999), cited in Fayolle et al. (2007), have shown that certain teaching methods such as traineeships and field learning are more successful than others at preparing students for an entrepreneurial career. Respondents felt that the lecturer was not helpful in providing practical talks from infopreneurs $10(62.6 \%)$ and yet Carrier (2007) is of the view that very rich, well known, and successful entrepreneurs can be excellent motivational speakers and role models for students, making students aware of the intrinsic rewards of self-employment. Respondents also felt that the lecturer was not assisting in group visits to information businesses $10(62.6 \%)$, and in relating his own infopreneurship experience 5 (31.3\%). Apart from imparting knowledge in the class, educators are given the responsibility to mould the personality and characters of students (Keat et al. 2011).

Fayolle, et al. (2007) opine that the educational variables such as course content, teaching methods, teacher profile, resources, and support have significant differences between students who have taken entrepreneurship courses and those who have not. During the focus group interview students clarified that they really needed to visit some infopreneurial businesses to familiarise with what actually happens in such businesses so that they could establish their own in future. It was also clarified during this interview that the respondents meant 'not helpful' when they said 'not sure'.

The focus group interview also revealed that students expected to be tasked to engage in more hands-on approaches and practicals such as selling information, books, and websites. Students also indicated that they expected to gain more exposure to infopreneurship businesses. This is consistent with Blenker et al. (2006), who suggest that experience has to be brought in from elsewhere in the form of guest lecturers from the 'real world'. The other aspect that emerged was that the module lacked resources such as books. Students pointed out that some of the recommended articles could not be accessed because their university (NUST) did not subscribe to the databases where the articles could be downloaded. Keat et al. (2011) argue that the ultimate aim of entrepreneurial programmes is to stimulate entrepreneurship awareness among students that, in turn, would increase their interest in entrepreneurship.

At the end of the questionnaire students were asked to make any other comment on the course Infopreneurship. The following is a summary of the respondents' comments with regards to the course: 'Can the course have some element of practicality in it in order to put theory into practice?'; 'The course is very helpful to us as students because we can actually start our businesses, be self-employed, after finishing degrees instead of sitting at home due to lack of employment in the country'; 'It is a relevant course regarding the unemployment levels in Zimbabwe'; 'It is a very good course which teaches relevant skills and is administered with simplicity that allows understanding by lecturer which is very helpful'; 'The course should involve aspects relating to financial management as well as risk management to ensure that the student is equipped with skills involved within the business'; 'It is a good course which can assist students to better manage their own businesses. However, students need visits to infopreneurship organizations'; 'lectures should have some practicals and students must be tasked to start businesses like what happens with the students for the BSc Honours Applied Chemistry entrepreneurship course'; 'The course should be complimented with systematic tours to infopreneurial firms and have seminars with practical infopreneurship'. This was consistent with Kassean et al. (2015) who note that for an entrepreneurship education programme to be effective, scholars have argued that it must emphasise actions in 
entrepreneurial ways and separate from traditional hallmarks such as business plan writing.

\section{Would you start your own business after taking and completing the Infopreneurship course?}

Respondents were asked if they would want to become infopreneurs after graduation. All 16 (100\%) students responded in the affirmative. Focus group interview data confirmed the questionnaire data. Table 3 presents the results from the focus group.

The results are consistent with Weber (2012) who opines that having gone through a course, students may now be more able to decide for the 'right' career path. The results confirm Ajzen's (1991) theory of planned behaviour that the formation of entrepreneurial intentions depends on perceived desirability, perceived social norm, and perceived behavioural control towards the behaviour in question.

\section{Conclusions and recommendations}

The paper is based on the study that aimed at investigating the NUST RAM students' perceptions on the infopreneurship course that is offered in their final year of BScRAM. It sought to address the following research questions.

- What motivates students to enrol for the BSc Honours Degree in RAM?

- Is the Infopreneurship Module a relevant course in the study of records and archives?

- What available resources are there for the teaching of the Infopreneurship course considering that it is a fairly new course?

- What challenges do part 4 students face when undertaking this course?

Results indicate that the majority of students did not apply to enrol for this degree, but found the infopreneurial module quite interesting, an eye-opener and relevant to their degree. The other finding was that the lecturer was helpful in providing to students such resources as books and electronic resources but students felt that they needed to visit some infopreneurial businesses for the purposes of familiarisation. They also looked forward to having guest lecturers from the real infopreneurial world. In line with the theory of planned behaviour and having gone through the infopreneurship course, students were prepared to undertake infopreneurial business after graduating from the university. The study proposed some recommendations for the programme.

TABLE 3: Respondents' view on starting an Infopreneurial business $(N=6)$.

\begin{tabular}{ll}
\hline Respondent & Respondents' view \\
\hline R1 & $\begin{array}{l}\text { The course is very helpful to us as students because we can actually } \\
\text { start our businesses, be self-employed, after finishing degrees instead } \\
\text { of sitting at home due to lack of employment in the country }\end{array}$ \\
R2 & $\begin{array}{l}\text { It is a very good course for students as it prepares us with the } \\
\text { necessary tools to engage into the real world and be better prepared } \\
\text { for what life has to offer }\end{array}$ \\
R3 & $\begin{array}{l}\text { The course is relevant especially to prepare students who are about } \\
\text { to finish their first degrees } \\
\text { It is a good course which can assist students to better manage their } \\
\text { own businesses }\end{array}$ \\
R4 &
\end{tabular}

Considering that students did not choose BScRAM as a first choice degree on application, the study recommends that the department of RAM can engage in advocacy to market the programme in order to bring awareness to high school students on the programme. This will motivate students to enrol for a programme of their choice. In view of the fact that students have found the course relevant to their degree programme (BScRAM) and in life, the study recommends that NUST may provide students with an opportunity and resources to start businesses such as to proofread final year students' research projects. Given the finding that infopreneurship is a relatively new discipline and as such resources are still scarce, the study recommends that NUST purchase some books relevant for the course. The study also recommends the subscription to some databases to assist in accessing some important online articles and e-books on infopreneurship. Another recommendation is the inclusion of varying teaching methods and activities in infopreneurship education that may include motivational speeches by successful infopreneurs, visits to infopreneurial businesses, and practicals such as drawing up a business plan or business proposal writing identified in local or international newspapers. The BSc RAM graduates would want to become infopreneurs in the future. In view of this conclusion the study recommends that the lecturers should regularly update the course outline to include some important topics on contemporary issues so that the entrepreneurial graduates will not face serious challenges in the field.

\section{Acknowledgements Competing interests}

The authors declare that they have no financial or personal relationships which may have inappropriately influenced them in writing this article.

\section{Authors' contributions}

D.P., a postdoctoral scholar, conducted the study as part of his postdoctoral studies at University of KwaZulu-Natal. M.S.M., the dean and head of School of Social Sciences and Humanities at University of KwaZulu-Natal, supervised the postdoctoral work.

\section{References}

Ajzen, I., 1991, 'The theory of planned behavior', Organizational Behavior and Human Decision Process 50, 179-211.

Ann, J. \& Carland, J. (eds.), 2010, Proceedings of the Allied Academies Internet Conference, Vol. 12, pp. 1-171, 14-17 April 2010, New Orleans: Louisiana.

Blenker, P., Dreisler, P., Faergeman, H.M. \& Kjeldsen, J., 2006, 'Learning and teaching entrepreneurship: Dilemmas, reflections and strategies', in A. Fayolle \& H. Klandt (eds.), International entrepreneurship education: Issues and newness, pp. 21-34 (eds.), International entrepreneurship education: Issues and newness, pp. 21-34,
Chetelham (UK): Edward Elgar Publishing Limited. http://dx.doi.org/10.4337/ 9781847201652.00008

Carrier, C., 2007, 'Strategies for teaching entrepreneurship', in A. Fayolle (ed.), Handbook of research in entrepreneurship education, volume 1: A general perspective, pp. 143-159. Chetelham (UK): Edward Elgar Publishing Limited.

Chandler, G.N. \& Jansen, E., 1992, 'The founder's self-assessed competence and venture performance', Journal of Business Venturing 7(3), 223-236. http://dx.doi. org/10.1016/0883-9026(92)90028-P

Chandler, S., 2007, From entrepreneur to infopreneur: Make money with books, eBooks and information products, Wiley, London.

Dilts, J.C. \& Fowler, S.M., 1999, 'Internships: Preparing students for an entrepreneurial career', Journal of Business and Entrepreneurship 11(1), 51-63. 
Du Toit, A., 2000, 'Teaching infopreneurship: Students' perspectives', Aslib Proceedings 52(2), 83-90. http://dx.doi.org/10.1108/EUM0000000007003

Fayolle, A., Gailly, B. \& Lassas-Clerc, N., 2007, 'Towards a new methodology to assess the entrepreneurship teaching programmes', in A. Fayolle (ed.), Handbook of research in entrepreneurship education, volume 1: A general perspective, $\mathrm{pp}$. 187-197, Chetelham (UK): Edward Elgar Publishing Limited. http://dx.doi. org/10.4337/9781847205377.00019

Henry, C.H. \& Letch, C. M., 2007, 'Evaluating entrepreneurship education and training: Implications for programme design', in A. Fayolle (ed.), Handbook of research in entrepreneurship education, volume 1: A general perspective, pp. 248-260. Chetelham (UK): http://dx.doi.org/10.4337/9781847205377.00024.

Hills, G., Hultman, C. \& Miles, M., 2007, 'Entrepreneurial marketing and university education', in Alain Fayolle (ed.), Handbook of research in entrepreneurship education, volume 1, a general perspective, pp. 219-229, Edward Elgar Publ. Ltd, Cheltenham, UK (in US: Edward 7 Elgar Publishing Inc., Northampton, MA).

Johannisson, B., 1991, 'University training for entrepreneurship: Swedish approaches', Journal of Entrepreneurship and Regional Development 3(1), 67-82. http://dx.doi. org/10.1080/08985629100000005

Kassean, H., Vanevenhoven, J., Liguori, E. \& Winkel, D.E., 2015, 'Entrepreneurship education: A need for reflection, real-world experience and action', International
Journal of Entrepreneurial Behavior \& Research 21(5), 690-708. http://dx.doi. org/10.1108/IJEBR-07-2014-0123

Keat, O.Y., Selvarajah, C. \& Meyer, D., 2011, 'Inclination towards entrepreneurship among university students: An empirical study of Malaysian university students', International Journal of Business and Social Science 2(4), 207-220.

Kirby, D., 2007, 'Changing the entrepreneurship education paradigm', in A. Fayolle (ed.), Handbook of research in entrepreneurship education, volume 1
A general perspective, pp. 21-45. Chetelham (UK): http://dx.doi.org/10.4337/ 9781847205377.00010

Kyro, P. \& Tapani, A., 2007, 'Learning risk-taking competences', in A. Fayolle (ed.) Handbook of research in entrepreneurship education, volume 1: A general perspective, pp. 283-306. Chetelham (UK):http://dx.doi.org/10.4337/ 9781847205377.00026

Lahm, R.J. Jr. \& Stowe, C.R.B., 2011, 'Infopreneurship: Roots, evolution, and revolution', Entrepreneurial Executive 16, 107-119.

National University of Science and Technology (NUST), 2015, Records and archives management, viewed 20 March 2015, from http://www.nust.ac.zw/index.php/ medicine/communication-information-science/records-archives-management

Ocholla, D.N., 1998, 'Information consultancy and brokerage in Botswana', Journal of Information Science 24(2), 83-95. http://dx.doi.org/10.1177/ 016555159802400203

Ocholla, D.N., 1999, 'Information intermediaries in the next millennium: An agenda for action for the development of information consultancy and brokerage in Africa', Library Management 20(2), 105-114. http://dx.doi.org/10.1177/ 016555159802400203

Ramugondo, L.S., 2010, 'An exploratory study of infopreneurship as a job option for Library and Information Science students: A literature review', paper presented at the 11th DIS Annual Conference 2010, Richardsbay, University of Zululand, South Africa, 02-03 September.

Storey, D.J. \& Greene, F.J., 2010, Small business and entrepreneurship, Pearson Education Limited. Harlow, Essex UK.

Weber, R., 2012, Evaluating entrepreneurship education, Springer Gabler, Wiesbaden. http://dx.doi.org/10.1007/978-3-8349-3654-7 